\title{
Poverty Reduction Through Pro-Poor Tourism: A Case Study of Handicraft Sector of Varanasi
}

\author{
Manisha Ashish Mehrotra \\ Assistant Professor, Department of Economics, Banaras Hindu University, Varanasi, India \\ bebugupta@gmail.com,manueco@bhu.ac.in
}

\begin{abstract}
Tourism continues to be a major activity in India, which inevitably produces economic, political, social, cultural and ecological consequences. In India, Tourism has created employment opportunities for airline executives, hotel sales managers, structural engineers, city planners, horticulturists, computer programmers, artisans, textiles workers, etc. In spite of its growth, it has not reached out to the masses because the net benefits accrue only to a limited segment of the society, to say, big business agents. It is an imperative duty of the so-called richer class to reach out the benefits directly to the Pro-Poor People who are actually working into the tourism sector day and night. Thus, Pro-Poor Tourism (PPT) is tourism that results in increased net benefits for poor people or marginalized section of the society. The aim of this paper is to explore the prospects and challenges of 'pro-poor tourism strategies' and its significance in poverty reduction by generating employment in handicraft sector of Varanasi in order to identify useful lessons and good practice for livelihood and capacity building, leadership and community development for sustainable development.
\end{abstract}

KEYWORDS: Pro-Poor Tourism, Employment Generation, Poverty Reduction, Livelihood and Capacity Building, leadership \& Sustainable Development

\section{Introduction}

World over tourism has emerged as one of the priorities of governments as a sector with immense potential for economic development, employment generation thereby reducing poverty. Various international agencies like the World Tourism Organization (WTO) have pointed out the vast developmental potential of tourism, particularly with reference to the developing nations, like India. It is widely recognized that economies like India and China would emerge as the superpowers in world tourism in the next 20 years or so.

In the year 2006, the foreign tourists' arrivals in India (4.45 million) have been almost doubled that of 1996 (2.29 million), while the earnings have almost tripled during the period, from Rs. 10046 Crore to Rs. 29604 Crore. Further, in line with the above increasing trend, for the seven months' period January to July 2007 the provisional figures stand at 2.76 million as against 2.47 for the corresponding period of 2006.

\section{Definition of Tourism, Pro-poor tourism \& poverty}

The World Tourism Organization defines tourism as 'The activities of persons travelling and staying in places outside their usual environment for not more than one consecutive year for leisure, business and other purposes.' However, we all know that Pro-poor tourism generates net benefits for the poor (i.e. benefits are greater than costs). Economic benefits are only one (very important) component - social, environmental and cultural costs and benefits also need to be taken into account. Pro-poor tourism strategies are concerned specifically with impacts on poor people, though the non-poor may also benefit. Strategies focus less on expanding the overall size of tourism, and more on unlocking opportunities for specific groups within it (on tilting the cake not expanding it) (Koch, with de Beer, and Elliffe 1998).

\section{Who are poor}

To define poverty is difficult. There is an international poverty line (US\$1.90 per person per day, averaged among household members) and most countries have a national poverty line, but these are hard to apply in the field. It is often more useful to identify disadvantaged groups by socio-economic 
status (landless labourers, female headed households, poor fisherman, etc) or use key indicators of poverty ( no regular wage income in the household, unable to eat $2 / 3$ meals a day). Such indicators are also useful for distinguishing the 'poorest' (e.g. dependent on others etc) from the 'fairly poor' (e.g. unskilled labourers, struggling, some casual work etc).

To fully understand the economic impacts of tourism on poor people, on the local and national economy, would require a considerable amount of data and a strong methodology. For example, while most effects of an increase in tourism revenue lead, eventually, to an increase in national income, the direct consequences for the distribution of this among households (and within households) are not necessarily the most favorable for reducing poverty.

Poverty may decrease for some and even increase for others. An increase in tourism provides a direct increase in income to those who supply the hotels, transport, and other services, and also to the host country through tax revenues and perhaps some service charges. It then provides indirect increases in income to others through the spending of the direct income. How these changes are distributed will determine the direct impact of tourism on poverty, thus distribution needs to be assessed. A major potential impact comes from how policy makers react to the increases in income: if they have a pro-poor orientation, they can both redistribute the income (through taxes and public spending) and influence its original allocation (e.g. by regulating the types of tourism). Therefore data on total tourism impact, information on where this comes from, and consideration of different types of impact, were considered and taken into account for drawing conclusions..

Advantages of Pro-Poor Tourism in poverty reduction: However, tourism does have some advantages over other sectors for delivering pro-poor growth (Deloitte and Touche, IIED and ODI 1999):

- Tourism delivers consumers to the product rather than the other way round. This opens up huge opportunities for local access to markets for other goods and services. Development strategies can enhance potential links to local enterprises and poor producers.

- Tourism does not face tariff barriers, although taxes on air travel can have a similar effect.

- Tourism has considerable potential for linkage with other economic sectors - particularly agriculture and fisheries. Realizing these linkages will increase the proportion of tourism revenue retained in the host country.

- There is a possibility of other types of linkages, for example, demand for tourism may add sufficiently to another sector's demand for the combination to provide a basis for introducing local provision of goods or services, (e.g. transport.)

- It may create an initial demand for a good or service that can then itself become a growth sector.

- Tourism provides opportunities for off-farm diversification. Tourists are often attracted to remote areas with few other development options because of their high cultural, wildlife and landscape values.

- Tourism provides relatively labour-intensive opportunities. It is more intensive than manufacturing and non-agricultural production, although less labour-intensive than agriculture. Its relation to the economy as a whole therefore depends on the relative weights of agriculture and manufacturing: this suggests that it is more likely to be among the most labour intensive sectors of the economy in more developed countries.

- Tourism can provide poor countries with a significant export opportunity where few other industries are viable. It appears to be more like manufactures, where comparative advantage can be created through a combination of identifying a possible product and creating a specialized demand.

- Tourism products can be built on natural resources and culture, which are assets that some of the poor have.

- The infrastructure associated with tourism development (roads, electricity, communications, piped water) can provide essential services for rural communities which would otherwise be excluded from general infrastructure provision.

- It has a high income elasticity, and therefore offers a relatively rapidly growing market. 
- Tourism may be expected to perform 'better' than traditional commodities, but not necessarily better than newer exports such as manufactured products.

- It can take different forms, using different inputs, and is therefore available to a wide range of countries (and regions within a country).

\section{Discussion}

Strategies for PPT can be broadly categorized into at least 6 types.

1. Expansion of business opportunities for the poor: e.g. have small enterprise development programmes (training/support/micro credit) been developed or markets expanded.

2. Expansion of employment opportunities for the poor: e.g. are unskilled jobs created and available to the poor.

3. Addressing/enhancing the environmental impacts of tourism that particularly affect the poor: e.g. any changes in access of the poor to land and natural resources. (Goodwin, Kent, Parker, and Walpole 1997).

4. Enhancing the positive and addressing the negative social and cultural impacts of tourism on the poor (e.g. sexual exploitation, loss of identity, women's economic participation, improved communication, health, schools, infrastructure, etc.).

5. Building a supportive policy and planning framework: e.g. encouraging government approaches that support PPT.

6. Developing pro-poor processes and institutions: e.g. decision-making that includes participation by the poor (whether in government, at local level, within a resort/enterprise etc).

7. Specific actions to involve the poor or address barriers to participation: Many barriers limit the economic involvement of the poor in tourism. Several were identified in Pro- Poor Tourism: Putting Poverty at the Heart of the Tourism Agenda, along with some suggested actions that can address them.

\section{Current Status of Handicraft Industries in Varanasi}

- In the primary survey of the MSMEs the main areas covered were Kandwa, Amara, Chandpur, Bhatti, Ramnagar, Chunar, Bazardiha, Khojwa, Assi, Sarnath, Samneghat neighbouring areas on the bank of Ganges.

- Various villages were specialized in the handicraft of specific items like Kandwa, Bhatti and Amara village had small units of clay toys e.g dolls animals, pots ,sigar etc.

- Ramnagar craftsmen now doing clay and pottery work but some eight to ten years back they were highly specialized in stone work and marble craftsmanship which due to lack of demand and upgradation of technology had declined.

- Chandpur has taken over the work of stone and marble is suburbs where various sculptures are made up of stone and marble and they are earning good amount of income due to their improved art and workmanship.

- Khojwa village is specialized in wooden handicrafts like small boxes, pen stand statues, chariots, flowerpots etc.

- Bazardiha once was highly specialized in Zari and Zardozi work but due to lack of financial and technical support the artisans are nearly facing acute poverty and are shifting to other areas for their livelihood. The art of Zari work and Zardosi requires great intricacy which is almost on the verge of decline now.

- Chunar area has opted for Plaster of Paris (POP)work instead of intricate enamelled carving on blue and white pottery which was once very popular art in the area.

There is also a center for Chinese clay work run by the Government of Uttar Pradesh in Chunar which gives training to the new workers but is currently not operating to its optimum level hence the artisans are forced to opt for other manual work like breaking of stones or working in MNREGA etc. as not much employment opportunities are available in this area. 
Table 1: Specific problems of 8 selected Handicraft industries

\begin{tabular}{|l|l|l|}
\hline Sr. No & Problems of Selected handicraft sectors & Main causes \\
\hline $\mathbf{1}$ & Wooden toys \& Artifacts & $\begin{array}{l}\text { Chronic poverty due to lack of any } \\
\text { government facilities } 65 \%, \\
\text { Lack of Infrastructure and marketing } \\
\text { facilities } 35 \%\end{array}$ \\
\hline $\mathbf{2}$ & Clay toys & $\begin{array}{l}\text { Lack of buyers } 80 \%, \\
\text { No credit facilities } 20 \%\end{array}$ \\
\hline $\mathbf{3}$ & Zardosi and Zari works on fabrics & $\begin{array}{l}\text { Lack of Infrastructure } 70 \% \text { \& } \\
\text { Illiteracy } 30 \%\end{array}$ \\
\hline $\mathbf{4}$ & Meenakari on pottery & $\begin{array}{l}\text { Lack of buyers } 45 \% \text { and } \\
\text { lack of availability of trained craftsmen } \\
\text { due to labour mobility } 55 \%\end{array}$ \\
\hline $\mathbf{5}$ & Glass \& Wooden beads & $\begin{array}{l}\text { Lack of Infrastructure } 55 \% \text { \& } \\
\text { Illiteracy } 45 \%\end{array}$ \\
\hline $\mathbf{6}$ & Glass bangles & $\begin{array}{l}\text { Lack of awareness } 42 \% \text { and } \\
\text { Chronic poverty } 58 \%\end{array}$ \\
\hline $\mathbf{7}$ & Brass \& Copper Artifacts & $\begin{array}{l}\text { High costs due to labour mobility } 65 \%, \\
\text { No credit facility } 35 \%\end{array}$ \\
\hline $\mathbf{8}$ & $\begin{array}{l}\text { Decorative Embroidery on Artifacts e.g. } \\
\text { hand bags wall hangings etc. }\end{array}$ & $\begin{array}{l}\text { Poor marketing facilities } 68 \% \text { and } \\
\text { lack of trained craftsmen } 32 \%\end{array}$ \\
\hline
\end{tabular}

Source: Compiled by author based on primary data collected from Varanasi

Results: From the table above it can be deducted that craftsmen working in different types of handicraft sectors are facing serious challenges clearly due to lack of infrastructure and any government support.

Further, Illiteracy and rampant poverty has compelled them to live with meager resources hence they are bound to live life below the poverty line. Government support is very much desirable here in this historic city.

Table 2: Link between PPT and Handicraft sector

\begin{tabular}{|l|l|l|l|}
\hline & Chi Square & \\
\hline Broad category & Value & df & $\begin{array}{l}\text { Asymp. Sig. } \\
\text { (2-sided) }\end{array}$ \\
\hline $\begin{array}{l}\text { Handicraft occupation* } \\
\text { Does Tourism Impact handicraft sector }\end{array}$ & 49.826 & 20 & 0 \\
\hline $\begin{array}{l}\text { Occupational Impact* } \\
\text { Has PPT increased any jobs in Handicraft sector }\end{array}$ & 22.999 & 16 & 0.014 \\
\hline $\begin{array}{l}\text { MSMEs Income } \\
\text { Does Tourism increase income of MSMEs }\end{array}$ & 51.604 & 20 & 0 \\
\hline $\begin{array}{l}\text { Income of small wage earners and Riksha pullers* } \\
\text { How has ppt affected small wage earners and their daily work }\end{array}$ & 21.366 & 16 & 0.015 \\
\hline $\begin{array}{l}\text { Work status * } \\
\text { Does tourism change their economic status }\end{array}$ & 37.129 & 10 & 0 \\
\hline $\begin{array}{l}\text { Social status * } \\
\text { How has PPT impacted their social lives }\end{array}$ & 5.631 & 8 & 0.009 \\
\hline $\begin{array}{l}\text { Role of Govt in Future* } \\
\text { How do you think in future Govt can bring change through ppt }\end{array}$ & 2.557 & 8 & 0.059 \\
\hline
\end{tabular}


Table 3: Correlation between PPT and Handicraft sector

\begin{tabular}{|l|l|l|l|l|}
\hline Broad category & \multicolumn{2}{l|}{ Correlation } & \\
\hline & Value & $\begin{array}{l}\text { Asymp. } \\
\text { Std. } \\
\text { Error }\end{array}$ & $\begin{array}{l}\text { Approx. } \\
\text { Tb }\end{array}$ & $\begin{array}{l}\text { Approx. } \\
\text { Sig. }\end{array}$ \\
\hline $\begin{array}{l}\text { Handicraft occupation } \\
\text { Does Tourism Impact handicraft sector }\end{array}$ & -0.183 & 0.073 & -2.511 & 0.013 \\
\hline $\begin{array}{l}\text { Occupational Impact * } \\
\text { Has PPT increased any jobs in Handicraft sector }\end{array}$ & 0.13 & 0.08 & -1.772 & 0.078 \\
\hline $\begin{array}{l}\text { MSMEs Income } \\
\text { Does Tourism increase income of MSMEs }\end{array}$ & -0.117 & 0.071 & -1.593 & 0.113 \\
\hline $\begin{array}{l}\text { Income of small wage earners and Riksha pullers * } \\
\text { How has ppt affected small wage earners and their } \\
\text { daily work }\end{array}$ & -0.33 & 0.065 & -4.727 & 0 \\
\hline $\begin{array}{l}\text { Work status * } \\
\text { Does tourism change their economic status }\end{array}$ & -0.144 & 0.058 & -1.973 & $.050 \mathrm{c}$ \\
\hline $\begin{array}{l}\text { Social status } \\
\text { How has PPT impacted their social lives }\end{array}$ & -0.096 & 0.058 & -1.301 & 0.195 \\
\hline $\begin{array}{l}\text { Role of Govt in Future* } \\
\text { How do you think in future Govt can bring change } \\
\text { through ppt }\end{array}$ & 0.222 & 0.083 & 3.079 & 0.002 \\
\hline
\end{tabular}

Source: Compiled by author based on primary data collected from Varanasi

Results: By the value of Chi square and Correlation test in between Linkage between Handicraft occupation to Tourism, we get that the association between them is highly positive with correlation 0.183 and chi square 49.826 which indicates the tourism will have positive linkage to handicraft occupation which will improve the occupation status positively. PPT relation to occupation shows a positive scenario with the chi square coefficient of association 22.99 and correlation 0.13 .

\section{Conclusion}

\section{Impact of tourism on the livelihoods of the poor}

Assessing the livelihood impacts of tourism in Varanasi is not simply a matter of counting jobs or wage income. Participatory poverty assessments demonstrate great variety in the priorities of the poor and factors affecting livelihood security and sustainability.

\section{Economic impacts}

PPT can generate four different types of local cash income generally involving four distinct categories of people:

- Wages from formal employment.

- Earnings from selling goods, services, or casual labour (e.g. food, crafts, building materials, guide services).

- Dividends and profits arising from locally-owned enterprises.

- Collective income: this may include profits from a community-run enterprise, dividends from a private sector partnership and land rental paid by an investor.

- However in Varanasi still the experiment has not been done therefore, it requires time to assess its real impact. 


\section{Policy conclusions}

Tourism development has not, to date, incorporated poverty elimination objectives. Participation by the poor in tourism, and the benefits they gain, depends on a range of critical factors including the type of tourism, planning regulations, land tenure, market context, and access to capital and training (Shah 2000). Many of these can be influenced by changes in policy or external support. Pro-poor interventions can and should be taken at three different levels:

- Strengthen rights at local level (e.g. tenure over tourism assets), so that local people have market power and make their own decisions over developments.

- Develop more participatory planning.

- Use planning gain and other incentives to encourage private investors to enhance local benefits.

\section{References}

Deloitte and Touche, IIED and ODI. 1999. Sustainable tourism and poverty elimination study. A report to DFID, UK.

Goodwin, H. J., Kent, I., Parker, K. and Walpole, M. 1997. Tourism, conservation and sustainable development. Final report to the Department for International Development. Available at www.ftsl.demon.co.uk.

Koch, E., with de Beer, G. and Elliffe, S. 1998. "SDIs, tourism led growth and the empowerment of local communities in South Africa." Development Southern Africa Special Issue, 15(5), summer 1998.

Shah, K. 2000. "Tourism, the poor and other stakeholders: Asian experience." ODI Fair-Trade in Tourism Paper. London: ODI. 